\title{
How do Potential Applicants Make Sense of Employer Brands?
}

\author{
Manfred Auer (D) - Gabriela Edlinger • Andreas Mölk
}

Received: 28 January 2021 / Accepted: 3 February 2021 / Published online: 24 February 2021 (C) The Author(s) 2021

\begin{abstract}
The aim of this paper is to investigate processes of subjective employer brand interpretations. We draw on the first-person perspectives of sought-after applicants who articulated their thoughts while being exposed to employer brand material and on subsequent in-depth interviews with the study participants about their assessments of the various employers' attractiveness. Sensemaking as a theoretical framework to understand meaning-making in processes of actors' engagement with artifacts is employed to analyze this qualitative data. Based on our empirical findings, we present a process model that illustrates how potential applicants make sense of employer brands. This dominant sensemaking journey includes three different stages: exploring the employer brand material, constructing a plausible employer image and assessing employer attractiveness. However, this trajectory is neither the only possible way nor completely linear and predictable since deviations, particularly the complete breakdown of making sense of employer brand material, are possible.
\end{abstract}

Keywords Employer Branding $\cdot$ Sensemaking $\cdot$ Employer image $\cdot$ Employer attractiveness

The datasets analysed during the current study are available from the corresponding author on reasonable request.

M. Auer $(\bowtie)$

Department of Organization and Learning, University of Innsbruck,

Universitätsstraße 15, 6020 Innsbruck, Austria

E-Mail: Manfred.auer@uibk.ac.at

G. Edlinger

Department of Organization and Learning, Research Group EBKOM, University of Innsbruck, Universitätsstraße 15, 6020 Innsbruck, Austria

A. Mölk

Division for Management in Health and Sport Tourism, UMIT TIROL,

Eduard-Wallnoefer-Zentrum I, 6060 Hall in Tirol, Austria 


\section{Introduction}

Establishing a reputation as an employer of choice is a priority for businesses due to a shortage of skilled workers (e.g., Sengupta et al. 2015). For example, the annual economic survey by Eurochambres (2019) identifies the lack of skilled workers as one of the biggest problems faced by European companies. Thus, businesses seek to achieve high levels of applicant attraction to be successful in competitive labor markets (Baum and Kabst 2014). The early stage of attracting potential applicants is crucial for this objective because later recruitment activities depend on its success (Walker and Hinojosa 2014). During this initial stage of the recruitment process, individuals interpret employment-relevant information, and organizations manage their employer image to convince qualified, suitable job seekers to join the applicant pool of an organization (Barber 1998).

Employer branding is a common management practice that aims to create and communicate a favorable employer brand in order to attract highly qualified applicants and retain valuable employees (Theurer et al. 2018; Martin et al. 2011; Edwards 2010). In this article, we focus on early recruitment processes from the perspective of potential employees. Employers use activities (e.g., walk-ins, recruiting fairs or career forums) and material (e.g., career websites, printed information, recruitment advertisements or promotional gifts) to communicate a positive employer image to job seekers. These employer brand activities and materials represent "one medium job seekers engage with to construct an image of the employing organization" (Appleby et al. 2018, p. 312). They are central contact points between potential employees and employers in the early stages of the recruitment process (Collins and Stevens 2002).

In this context, this paper addresses the question "How do potential applicants make sense of employer brand material?" We adopt an interpretive lens for the analysis of original qualitative data on highly qualified potential applicants' engagement with employer brand material. Thereby, we aim to address critical limitations of employer branding literature that stem from the predominant focus on controllable factors and outcome measurements in quantitative employer branding research: Potential applicants' subjectivity and the fluidity of employer brands are excluded from established conceptualizations of employer branding. Therefore, insights about potential applicants' processes of interpretation of employer information lack crucial knowledge. For example, what are different dynamics that might occur when job seekers engage with employer brand material? How do employer information, factors not controllable by employers (e.g., word of mouth, media reports, the regional reputation of an employer) and the subjectivity of individuals interact within the process of interpreting employer brand material? Questions that acknowledge the real-life complexities of employer branding processes are excluded from traditional employer branding research. Aggerholm et al. (2011) and Smith (2018) stress a necessity to acknowledge stakeholders' active roles in the co-creation of employer brands.

In order to contribute to the development of this line of research, our paper applies sensemaking as a theoretical framework (Weick 1995) to analyze the subjective and contextual factors at play in the process of an actor's engagement with branded 
artifacts. Sensemaking is an established lens in interpretive studies on management and organization (e.g., Maitlis and Christianson 2014; Jansen and Shipp 2019). It is based on the insight that, rather than simply perceiving the outside world (situations, events, tools, information, etc.) and the self, people actively create meanings about their circumstances and themselves (Weick et al. 2005). To account for this personal and social process in the context of employer brands, we provided highly qualified potential applicants with employer brand materials that were prepared by prospective employers in their field of expertise. The study participants were given camera glasses to wear and were asked to articulate their thoughts while engaging individually with the employer brand materials. We subsequently interviewed them about their perspectives on the employers in the study and eventually conducted a sensemaking-based template analysis of the complete data.

By providing a qualitative, process-oriented account of potential applicants' sensemaking of employer brand material, this paper contributes to research on employer branding in two ways. Firstly, our study provides insights into potential applicants' various activities when engaging with employer brand material. Through the explorative methodological design of our study, we do not restrict the focus of the study to specific factors and effects of these activities. Secondly, based on the empirical findings and the sensemaking approach, we propose a process model that links the identified activities into a central but flexible trajectory of potential applicants' making sense of employer brand material. This model shows how subjective employer brand interpretations unfold and thereby contributes to the conceptualization of this core aspect of employer branding. More generally, our analysis of how potential applicants co-author employer images and construct subjective interpretations of employer brand material driven by plausibility and identity construction furthers a perspective on employer branding that acknowledges subjectivity and fluidity as part of the employer branding process.

In the following sections, firstly, we outline the limited role of subjectivity and active agency and the static concept of process within the predominant quantitative research on employer branding. We then propose a perspective on employer branding that emphasizes subjectivity and process dynamics. Secondly, we introduce sensemaking as a theoretical framework that allows us to capture the dynamic processes of subjective interpretations of employer brands. Subsequently, we explain the methodological design of our study of processes of subjective assessments of employer attractiveness. Following the presentation of empirical findings, which we structured along the main themes from the template analysis conducted, we provide an in-depth discussion of the key elements, activities and patterns in potential applicants' sensemaking of employer brands. We conclude by emphasizing uncertainty and flexibility in processes of making sense of employer brands, and finally, we combine limitations of our study with suggestions for future research. 


\section{Conceptual Background}

\subsection{Proposing a Subjective and Process-oriented Perspective on Employer Branding}

Since Ambler and Barrow (1996) originally coined the term employer branding, research on this topic has progressed in several regards (see the reviews of Theurer et al. 2018; Lievens and Slaughter 2016). Besides conceptual articles (e.g., Backhaus and Tikoo 2004; Edwards 2010; Martin et al. 2011), a steady stream of predominantly quantitative empirical research has been conducted in the field of employer branding, particularly in terms of analyzing the effects of employer brand activities and material on potential applicants' perceptions of employer images and attractiveness (e.g., Onken-Menke et al. 2018; Kashive and Khanna 2017; Baum and Kabst 2014). Additionally, employer branding studies have investigated current and potential employees' perceptions of attributes of organizations as employers (e.g., Kumari and Saini 2018; Edwards and Edwards 2013; Van Hoye et al. 2013; Lievens 2007; Lievens and Highhouse 2003). However, despite the extensive and sophisticated ways in which researchers have studied employer branding, we identify two considerations that have largely been underdeveloped to date: a more holistic, subjective view on employer branding that acknowledges potential and current employees' agency and their specific socio-cultural contexts and an emphasis on the process of how subjective interpretations of employer brands unfold.

Firstly, our study provides a qualitative exploration of how potential applicants holistically and subjectively interpret employer brand material. Traditional research on employer branding offers robust quantitative measures of the impact of various dimensions of employer branding activities and characteristics of potential employees on perceptions of employer images and identities. Particularly, studies on employer brand activities and material such as organizational job or recruitment advertisements (e.g., Baum et al. 2016; Acarlar and Bilgiç 2013), recruitment websites (Chen et al. 2012; Walker et al. 2011; Allen et al. 2007, 2004; Cober et al. 2004) or career fairs (Cable and Yu 2006) offer detailed quantitative analysis of the attitudes and reactions of job seekers in this context. Among the various employer branding features previously examined are the role of media richness in applicant attraction (Cable and Yu 2006; Baum and Kabst 2014), the content of employer information, such as flexible work practices (Onken-Menke et al. 2018; Kröll et al. 2018) and corporate social responsibility (Carlini et al. 2019). Along with this, potential applicants' personal characteristics and their familiarity with the organization (Walker et al. 2011), their job pursuit intentions (Hinojosa et al. 2015) and congruity between recruitment advertisements and organizational image (Baum et al. 2016) have been analyzed. Additionally, some studies explored the influence of company-independent sources, particularly word of mouth (e.g., Stockman et al. 2020; Van Hoye and Lievens 2009), on initial attraction to employers. However, this research does not capture how addressees characterize and understand employer branding more holistically, where multiple sets of activities and material produced by employers and by external sources intermingle to form an overall subjective evaluation. Moreover, addressees of employer branding are usually conceptualized as information processing entities 
within the theoretical concepts and research designs used. In contrast, we theorize potential applicants as "meaning-making creatures" (Smith 2018, p. 50), as the authors of their interpretations of employer brand activities and material, and thus give their agency a more active role within employer branding (Aggerholm et al. 2011). Their interpretations are then characterized by their subjectivity and embedded within their specific social and institutional context (Appleby et al. 2018). Thus, we qualitatively explored individuals' thoughts on employer brand activities and material and their responses to general questions regarding the employers involved and their employer brand materials.

Secondly, we used a process lens that has received little attention in the employer branding field. Thereby, our approach focuses on how potential applicants develop employer images and attractiveness when engaging with employer brand activities and material. Our approach stands in contrast to prior process-oriented studies on job seekers' perceptions of employer brand activities (e.g., Hinojosa et al. 2015) as this research is usually founded on a process ontology based in "substantive metaphysics" (Langley et al. 2013, p. 5). This view conceptualizes organizations and individuals as fixed identifiable entities and focuses on changes in these entities over time (Langley et al. 2013). The elaboration-likelihood model (ELM) (Petty and Cacioppo 1981), as the most influential process theory within employer branding and recruitment research, precisely reflects this process perspective (e.g., Baum et al. 2016; Collins and Kamar 2014; Uggerslev et al. 2012). The ELM addresses the role of contextual and individual variables in the intensity of individual information processing, offering a distinction between a peripheral and central route of processing (Collins and Kamar 2014). Within this model, the variables that influence information processing are separated from the process itself and thus held constant. It mainly focuses on the question "[w]hich recruiting information predicts applicant attraction and job choice behavior" (Uggerslev et al. 2012, p. 601). Thus, employer branding studies based on ELM regard changes in the intensity of individual processing of information as something that happens to individuals viewed as fixed identifiable entities.

Our approach, however, is based in "process metaphysics" (Langley et al. 2013, p. 5). From this perspective, "the world is made up of processes rather than things [...], of events and experiences rather than substantial entities" (Langley et al. 2013, p. 6). It emphasizes how processes themselves emerge and develop. In contrast to substantive metaphysis, in process metaphysics, context is not something outside the analyzed developments "but is itself continually reconstituted within and by processes of interaction over time [...], generating unexpected and largely uncontrollable chains of activity and events in which actors, environments and organizations are all in constant and mutually interacting flux" (Langley et al. 2013, p. 6). This approach is more suitable to explore how meaning is ascribed to and constructed around employer branding, how these interpretations unfold and how the complex interplay of ongoing employer brand activities and material, social dynamics and identity constructions constitute this process. 


\subsection{Sensemaking as a Theoretical Approach}

To examine a subjective and process-oriented view on employer branding and thus develop a better understanding for how potential applicants subjectively make sense of employer brands, we refer to a cognitive sensemaking perspective (Sandberg and Tsoukas 2014; Weick 1995). We understand sensemaking as a process of meaning construction whereby people interpret events, issues or physical representations that are complex, surprising or ambiguous (e.g., Brown et al. 2015; Maitlis and Christianson 2014; Cornelissen 2012). Sensemaking goes beyond interpretation and includes "the active authoring of the situations in which reflexive actors are embedded and are attempting to comprehend" (Brown et al. 2015, p. 267). Thus, within the individual construction of employer images, addressees of employer branding are not mere objects but co-creators of these brands. Constructions of their own identity and how they relate these constructions to an employer plays a fundamental role within this process. This reflects the relevance of identity constructions as a basic property of sensemaking (Brown et al. 2015; Weick et al. 2005). Individuals try to create meaning from unclear situations and ambiguous stimuli "in ways that respond to their own identity needs. They are able to draw creatively on their memory ... in composing a story that begins to make sense of what is happening while potentially enhancing their feelings of self-esteem and self-efficacy" (Coopey et al. 1997, p. 312). Sensemakers make sense of themselves and the outside world, and both processes influence each other (Brown et al. 2015), "but the direction of causality flows just as often from the situation to a definition of self as it does the other way" (Weick 1995, p. 20).

Organizations can influence sensemaking processes of individuals to increase their organizational identification by relating positively to their assumed identity and values but also by creating doubt and ambiguity in individuals. Pratt (2000) studied the latter in the context of new distributors in a network marketing organization and characterizes this organizational strategy as "sensebreaking". Sensebreaking aims to generate some degree of uncertainty about new organizational members' own sense of self and incite interest in the organization at the same time and thus provide a strong motivation to familiarize oneself with the organization. According to Pratt (2000), this motivation is related to a challenge to one's identity that leads to "seekership," defined as "a desire to find meaning that originates from a sense of discontentment about who one is" (464). By means of employer branding, organizations can also challenge the identity of potential applicants and attempt to make employers more interesting for them.

Processes of sensemaking are also fundamentally social since even in situations where individuals create meaning on their own, as they do in our study, they "are embedded in a sociomaterial context" (Maitlis and Christianson 2014) where their thoughts and feelings are influenced by the actual, imagined, past or potential presence of others (Weick 1995). The interpretation of employer brand activities and material, and thus the co-creation of employer images and attractiveness, has a strong social character (Aggerholm et al. 2011) since it is influenced by interactions with peers, friends and family and their experiences with employers and the labor market. 
Moreover, direct talks with representatives of potential employers during a career fair, a school visit or a job interview can also affect this process.

The answers to the two central questions in sensemaking (Who am I? What is going on?) are influenced by "institutional expectations of how actors should perform an identity in specific situations" (Weber and Glynn 2006, p. 1646). In the context of individuals creating meaning for employer brands, institutional aspects such as structures of the specific labor market (e.g., gendered labor market segmentations) or the reputation of work in a specific industry (e.g., problematic reputation of workplaces in the tourism industry) are of relevance.

A sensemaking perspective must also acknowledge the possibility of failures and breakdowns of meaning constructions. This "collapse" of sensemaking (Weick 1993) usually "highlights the failure of the activated frame to guide inferences meaningfully in real time, or worse, its tendency to blind individuals to an alternative interpretation" (Cornelissen and Werner 2014, p. 189). We relate to these interpretations of failures of sensemaking but add the problems of agents' passivity in a sensemaking process and the refusal to create meaning in a specific context, which also lead to a meaning void.

Finally, we draw on the distinction between priming and framing suggested by Cornelissen and Werner (2014). They analytically divide instances in which alreadyavailable schemas (e.g., pre-conceived opinions, existing accounts) are activated and drive interpretation (i.e., priming) from those instances where new meanings are actively constructed by individuals in context (i.e., framing). Priming denotes the activation of individuals' already-available cognitive schemas in encounters (Cornelissen and Werner 2014). It considers responses that are triggered by perceptual cues that call to mind certain schemas and "corresponding performance scripts without much deliberate thought" (Weber and Glynn 2006, p. 1646). In our study, priming refers to the activation process of pre-existing concepts of employment, employers, work or career that are grounded in past experiences and predetermined convictions. Thus, the concept of priming stresses the activation of an individual employer image as an "attentional process ... to that which has already occurred" (Weick 1995, p. 25). Priming must therefore be considered as a mainly retrospective meaning creation method that follows initial perceptual processes.

Framing, by contrast, refers to emerging perspectives (e.g., novel views on an employer) that are sparked by novel information and signals or by understanding and contextualizing existing knowledge or messages differently (Cornelissen and Werner 2014). The framing aspect within sensemaking stresses reflexive actions and reasoning. It particularly acknowledges processes through which actors identify and evaluate their experiences (Weber and Glynn 2006). Framing stresses the prospective in sensemaking (e.g., Sandberg and Tsoukas 2014; Cornelissen and Clarke 2010) as it also aims "at creating meaningful opportunities for the future" (Gioia and Mehra 1996, p. 1229). Thus, when potential applicants engage in framing employer brand activities and material, they are guided by past employment experiences, the present context and their expectations of future employers, employment or career aspirations.

We conceptualize sensemaking as embracing both of these aspects within a dualprocessing model of meaning creation, distinguishing perceptual processes of prim- 
ing from reflexive, deliberate reasoning processes. Priming and framing as two aspects in meaning construction often relate to each other in recursive processes of influence (Cornelissen and Werner 2014). To account for those dynamics, we designed the following dual-step research strategy that covers potential applicants' engagement with employer brand activities and material and their processes of assessing the related employers.

\section{Method}

\subsection{Study Preparation and Recruitment of Suitable Participants}

In preparation for our study, we identified four tight labor market sectors based on information provided by the regional governmental job center. We then contacted managers of the largest employer for each branch, to find out what type of workers they aimed to attract and who their main competitors in the labor market were. We used this information to identify pools of companies that were competing for the same set of potential applicants. Next, we invited the identified companies' HR managers to participate in our study by providing the employer brand information they offer to potential applicants from relevant professional schools and advanced technical colleges. In return, we offered to provide them with a written summary of overall findings for their sector. To reach our goal of having four companies from each sector, tourism, electrical engineering, civil engineering and timber technology, we contacted 17 companies. One company rejected our request because it was in the process of developing its employer profile at the time and was not ready to supply us with its standard portfolio of employer brand material.

To recruit suitable participants for our study, we asked educators in selected advanced technical colleges and professional schools whose graduates are a key target group of the companies' employer branding efforts to recommend highly qualified students from their current graduation class. The educational institutions selected are devoted to practical expert education in their main subject areas and require their students to work for extended periods of time (in internships or as part of dual education programs) before they can graduate. Average full-time work experience among the 47 participants in our study was 6.1 months among the $36 \%$ who had completed internships and 4.6 years among the $64 \%$ who had already worked for an extended period. In our sample, $34 \%$ of participants were qualified professionals in the field of tourism, $23.4 \%$ in electrical engineering, $21.3 \%$ in civil engineering and $21.3 \%$ in timber technology. By means of this sampling strategy, we created pools of rival employers in tight labor market segments, who actively competed for the potential applicants in our study. 


\subsection{Data Collection}

Our data collection comprised of two consecutive procedures:

\subsubsection{Phase 1: Concurrent Verbalization of Making Sense of Employer Brand Material}

The employer brand materials provided by the employers ranged from product samples to employer-related informational material to giveaways. These artifacts were put in uniform boxes, which were positioned randomly on a table before each respondent entered the room. On their arrival, participants were equipped with camera glasses-miniature cameras worn at eye level to capture an actor's perspective (Lahlou et al. 2015). To avoid potential irritation or awkwardness, we used ordinary-looking glasses with a camera lens built in at the right side of the frames. The participants were led to the table of boxes and received the following instructions: "There are four boxes on the table in front of you. In each of the boxes, you will find material that potential employers have provided to present themselves. We now would like you to take a look at these materials and to articulate your thoughts. Simply say out loud whatever comes to your mind." This procedure combines the idea of eliciting employer brand knowledge via artifacts (e.g., Heisley and Levy 1991) with concurrent verbalization as a way of collecting data on cognitive processes to uncover reasons, motivations and process-related structures of behavior (Ericsson and Simon 1998). By asking for verbalized thoughts rather than for participants' descriptions of their decision-making process (procedural verbalization), the instructions were designed to foster associative verbalization in order to avoid detrimental effects on respondents' focus on the main task (Fox et al. 2011; Dickson et al. 2000).

\subsubsection{Phase 2: Retrospective Inquiry of Making Sense of Employer Brand Material}

The study participants' opinion-making process was followed by one-on-one, semistructured interviews. Respondents were invited to identify the companies that they considered the most and least attractive employers and were then asked about their decisions and their opinions on the selected companies. The interviewers asked follow-up questions regarding the opinions given, exploring motives and contexts within the subjective assessments of the employer brands. At the end of each interview, we collected information regarding the respondent's personal and professional situations.

\subsection{Data Analysis}

To prepare our data for analysis, we first created verbatim transcripts of the audio data and then used the video data to add information on nonverbal activities (e.g., $\{[$ pokes through the box $]$ ). When analyzing the visual data, we focused on the respondents' physical handling of the employer brand materials. The information from the video data was used to unambiguously associate participants' statements 
with the respective employers in our study and as a supplementary source to support our interpretations of participants' statements. After the transcripts of the audio data had been complemented with the notes on nonverbal activities, we conducted a template analysis (King 2012) using the software ATLAS.ti (ATLAS.ti Scientific Software Development $\mathrm{GmbH}$ ). Template analysis "balances a relatively high degree of structure in the process of analyzing textual data with the flexibility to adapt it to the needs of a particular study" (King 2012, p. 426). We began our data analysis with the inductive coding of a random subsample of 12 transcripts. Each of the three authors individually conducted open line-by-line coding for four of the 12 transcripts with the aim of developing categories for an initial coding template. We then collectively discussed our coding suggestions against the background of the theoretical themes and subthemes reflecting the conceptual distinction between priming and framing (Cornelissen and Werner 2014). This process of combining thematic categories from the conceptual framework with inductively generated codes resulted in an initial coding template, which was entered as a code hierarchy in ATLAS.ti. As a result, from the first inductive coding step, two conceptual themes ("priming" and "framing") were supplemented by two additional main themes ("dynamics between and within priming and framing" and "withdrawing from sensemaking"). Based on the initial coding structure, we began coding the complete data. During this part of the coding process, the initial template was adapted several times to incorporate new findings until the coding structure was suited to the overall data set. To facilitate the development of the template, the three authors met at least once a week during the period of data analysis to review the coding and discuss data-based adaptations to the coding template. These discussions were based on the current versions of the following three Atlas.ti export files, which were used to summarize the coding: the codes-primary-documents-table, the code hierarchy and the complete codes-quotation report. The agreed final template that resulted from this process was used to code the complete data set. This coding structure is shown in Table 1, 2, 3 and 4 in the Findings section. The following findings report focuses on phenomena that were evident across the data set and were essential parts of the observed opinion-making processes. Exemplary quotes for codes are provided in one table for each root code.

\section{Findings}

Participants' engagement with employer brand material started with their initial reaction to the particular employer. When looking at the material provided, in almost all cases, the study participants started the thinking aloud process by saying the company name and stating whether they were familiar with this employer. However, irrespective of existing employer knowledge and of the nature of preconceptions, in all cases except one these initial reactions were followed by continued engagement with the branded artifacts. In one instance, the first impression of the employer brand material led to the immediate, spontaneous rejection of that employer. In all other documented employer brand encounters, the potential applicants continuously engaged with the material provided by the companies. This early phase of the observed sensemaking process was marked by the key role of priming. 


\subsection{Schema-driven Creation of Fragmentary Employer Attributions}

The participants' initial engagement with the employer brand material provided by the companies allowed them to explore the information and branded artifacts available. The aim of gathering information and developing a general first impression of each employer's features manifested in the respondents' browsing through the employer brand material and providing ad hoc comments about isolated features and contents of these artifacts (Table 1, Codes 1.1.1 and 1.1.2). ${ }^{1}$

In their early investigation of the material, respondents took a rather analytical approach and were very matter-of-fact in their statements. However, their interpretations of the features and contents that stood out to them were subjective in the sense that they were strongly guided by priming effects. Depending on the respondents' degree of familiarity with each company and the amount of their work experience in the specific industry, the activated schemas used to interpret employer brand material were either predominantly general or employer and industry specific. General schemas were particularly frequent points of reference in the absence of strong and prevailing employer- or industry-related preconceptions. As a quotation from study participant Steve's engagement with the material illustrates (Table 1, Code 1.2.2), these general schemas reflected respondents' general assumptions about trends, their associations with particular sensory or visual stimuli (e.g., paper quality, colors, visual contents) and their views on topics addressed in or associated with the material.

In addition to general schemas, company- and industry-specific schemas were crucial reference points when study participants already held views on the company image or selected features of the company (e.g., its products or services, its target audience, its locations, or its organizational form, structure or size) or the industry in question (e.g., specific industry segments, standards and customs). For example, study participant Claire's responses to employer brand material reveal that she links family-owned businesses, as a general company feature, with positive attributes (Table 1, Code 1.2.1.2). Meanwhile Isaac's assertion that a brochure from company CE2 indicates the company's promising prospects for success is preceded by an expression of his positive view of tunnel construction businesses (Table 1, Code 1.2.1.1). These excerpts from Claire's and Isaac's exploration of information material also show that in some cases, when company- or industry-related schemas were activated, they influenced respondents' overall perception of employer brand materials or directed their attention to particular aspects of the employer information. A similar dynamic is evident in the passage from Mary's employer brand encounter displayed in Table 1, Code 1.2.1.3, where the strong impact of her preconceived image of a particular organization as "traditional" led her to interpret a wood-covered USB stick as the epitome of tradition.

However, in no case within our data was a respondent's interpretation fully determined by familiarity. Although Mary clearly perceived TO2's image to be traditional

\footnotetext{
${ }^{1}$ Companies' names are displayed as TO1-TO4 for tourism, EE1-EE4 for electrical engineering, CE1-CE4 for civil engineering and TT1-TT4 for timber technology enterprises. Study participants' names are pseudonyms. The transcription symbols used follow the suggestions of Gumperz and Berenz (1993).
} 
Table 1 Codes associated with root 1, "Priming"

Code Sample Quote

\subsection{Perceiving cues}

1.1.1 Perceiv- $\quad\{$ ? [pokes through the box]\}? TT3, of course* I know them. They have research ing features projects with us./ \{?[takes giveaways out of the box]\}? I prefer this much more. At of Employer least there are Post-its that are handy./ \{? [looks at a book, takes it out of the box and Branding measures its weight with his hand]\}? And then there is a book about the apparently $(E B)$ material about the founder of the company. If this is really necessary to say something about the company, I don't know, but it's the bomb.*/ Yes, that looks really* good,/[...] but anyway, they put a lot of effort into it/ (P43_Luigi)

1.1.2 Perceiv- $\quad\{$ ? [takes a folder out of the box and looks at the text]\}? My first impression of the ing contents mission statement,/ it does really make you think and wonder, at least for a moment. of EB mate- $\quad$ \{? [takes company information material in form of a magazine in hand] $\}$ ? An emrial ployee and guest magazine,/ that makes everything a little more tangible for the guests about what is going on in the background./ (P18_Lena)

\subsection{Attributing schemas to perceived cues}

\subsubsection{Drawing on company-and industry-specific schemas}

\subsubsection{In-} dustry-related schemas

\subsubsection{Com-} pany-related schemas not linked to one single company 1.2.1.3 Company-related schemas linked to a particular company

\subsubsection{Draw-} ing on company- and industrynonspecific or general schemas
$\{?$ [slowly browsing through a magazine; looking at the written and visual content of the first pages]\}?/ It is nice to see something about civil engineering in the beginning. That is better than cars. \{?[points at the box of another employer]\}?/ I prefer tunnel construction. I like this sentence/ if I want to work professionally in my area of expertise/ $\{$ ? [reads it out loud] $\}$ ? "Your careers with CE2, your decision to join our community." Yes, you get a feeling from this brochure that the future is secured at CE2. // (P47_Isaac)

That is founder's name's book. $<2>$ With this, they point out again that it is a family business, and this represents its personality./ We are a family business. You will feel right at home here with us./ There is not just a focus on profits./[...] From the beginning, you just always have a positive impression./ (P38_Claire)

I am going to start with TO2./ \{? [poking through the box; takes a company magazine out of the box]\}? The traditional aspect strikes me right away./ Not just the crest inside the ring; the font is also very traditional./ This is what I would associate with TO2./ It is not a modern hotel but a traditional and luxurious one. [...]\{?[opens a small box containing a memory stick in wooden design]\}? What is it? \{?[takes the memory stick out of the box]\}? Um, okay, a memory stick./ Yes, that is a great idea./ Also, the traditional aspect again, the wood. I think that reflects it pretty well./[...] I believe that actually builds on the traditional, respected hotel image, that that is the crucial reason to work there. (P30_Mary)

They are on the pulse of time because they have one of those cloths to clean your smartphone screen, plus a USB stick, plus large images that I really like./ Exactly, letting images speak louder than words./ What I don't like is that there are models in almost all or most pictures./ In my opinion, this is simply not customary anymore./[...] they introduce the employees. I like that./ It shows how valuable all employees are. $\{$ ?[intensively studying the material] $\}$ ? This creates the impression that the employee is valuable. (P26_Steve)

and luxurious, parts of her interpretation of employer brand material, such as her comments regarding the hotel magazine, were not affected by this view. In addition, if participants were familiar with a company but did not have a strong and clear perception of its image, familiarity did not appear to affect the initial interpretation of employer brand material strongly. For instance, in the quotation displayed in Table 1, Code 1.1.1, Luigi immediately emphasized that he was familiar with company TT3, 
but his previous employer knowledge was not mentioned in his statements about features of the employer brand material.

\subsection{Frame-driven Construction of a Plausible Employer Image}

Once study participants had engaged with the employer brand material sufficiently to develop a first impression, they drew on their created employer attributions and-by adding new, original thoughts-started to create more holistic, congruent employer images. Unlike the schema-driven reactive creation of employer knowledge in response to the material, participants' attempts to construct an employer image were characterized by active reasoning for or against particular interpretations. For most participants, their impressions of the employers from the initial exploration of their respective brand materials did not translate smoothly into a congruent employer image. In fact, participants formulated a consistent image immediately after viewing the employer brand material in only a few cases (Table 2, Code 2.1).

Those participants whose perceptions were not consistent felt compelled to at least address perceived inconsistencies. Some tensions arose from respondents' interpretations of divergent features or contents of the material provided. For example, Jack pointed out that he considers owning a shark tank to be incompatible with the ecological focus claimed by TO2 (Table 2, Code 2.2.1). The most frequently addressed tensions were differences between perceived messages from the employer brand material and other information sources, such as word of mouth or participants' own experiences (Table 2, Code 2.2.2).

If faced with divergent attributions for an employer and multiple options for interpretations, participants usually went beyond simply identifying divergent meanings and engaged in the active construction of consistent images in four ways. Firstly, in most cases potential applicants added more evidence that is consistent or used argumentative strategies to explain the plausibility of their chosen interpretation (Table 2, Code 2.3.1.3). Secondly, if participants were familiar with a company, common approaches to sustain their interpretations were for respondents either to use their preconceived ideas of the employer's image as a frame to create a storyline or to disclose their previous knowledge about and experiences with an employer. Martha, for example, presented her memories of an organized company visit she had participated in during her studies in the context of her overall impression of TT2 as a tough and cynical employer. As is evident in Martha's statement, referenced in Table 2, Code 2.3.1.1, she interprets employer brand materials in the light of her previous employer brand experience. Her account contains references to brand information from different sources. These include the organization (the workplaces and the company representative's statement), Martha's subjective experiences and her assessments (her individual interpretation of the working conditions and her memories of the experience), and a particular social context (the running joke between the study participant and her peers), all of which she presents to fit her overall narration. Thirdly, some participants actively questioned and revised some of their prior brand attributions resulting in more consistent brand perceptions. For example, Robert's admission of his negative preconception of one particular employer (displayed in Table 2, Code 2.3.1.2) allowed him to put his previous negative attributions 
Table 2 Codes associated with root 2, "Framing"

\begin{tabular}{ll}
\hline Code & Sample Quote \\
\hline $\begin{array}{l}\text { 2.1. Emphasiz- } \\
\text { ing proposed } \\
\text { consistent attri- } \\
\text { butions }\end{array}$ & $\begin{array}{l}\{\text { ? } \\
\text { workamines the material closely] }\} \text { ? The way I see it from the material, when you work in a young, dynamic team with a focus on teamwork./[...] }\end{array}$ \\
& $\begin{array}{l}\text { Work is more than just work, but it is a place where you can live your hobbies as } \\
\text { well./ You can also have fun at work by working out or experiencing so many other } \\
\text { things which are offered there./ So many benefits included:/ a gym, an outdoor pool } \\
\text { for employees to use./[...] From the benefits that I see here, it seems like a working } \\
\text { vacation:/ breakfast buffet with fresh eggs. It actually looks like stuff for guests and } \\
\text { not for employees./ Yes, exactly, those images speak volumes. (P3_John) }\end{array}$
\end{tabular}

\subsection{Addressing perceived inconsistencies}

\begin{tabular}{|c|c|}
\hline $\begin{array}{l}2.2 .1 \text { Highlight- } \\
\text { ing perceived } \\
\text { inconsisten- } \\
\text { cies in the EB } \\
\text { material }\end{array}$ & $\begin{array}{l}\text { Actually, when I heard of it, I didn't know that TO2 is a eco hotel. I only learned } \\
\text { about this when I got there./ I had a completely different image in mind because of } \\
\text { all the famous people who go there and all these parties./ That was my association,/ } \\
\text { and what I also don't get and what doesn't fit at all is this weird thing here in the spa } \\
\text { area./ That really isn't suitable for an eco-hotel. }<3>\text { (P22_Jack) }\end{array}$ \\
\hline $\begin{array}{l}\text { 2.2. Highlight- } \\
\text { ing perceived } \\
\text { inconsistencies } \\
\text { between EB ma- } \\
\text { terial and other } \\
\text { information }\end{array}$ & $\begin{array}{l}\{?[\text { opens the brochure }]\} ? \text { When I am looking for a job, and I look at this company } \\
\text { name and see the photos and the house and also the welcoming messages and so } \\
\text { on, then I would apply right away because it just seems cozy, and it seems like } \\
\text { a nice working atmosphere. [...]/ However, in my opinion, since I have already been } \\
\text { there, I probably wouldn't go there anymore/ because the working climate amongst } \\
\text { service staffers wasn't* good at all. (P11_Jules) }\end{array}$ \\
\hline
\end{tabular}

\subsection{Constructing consistent images}

\subsubsection{Excluding incompatible attributions, highlighting compatible attributions}

2.3.1.1 Selecting coherent attributions

\subsubsection{Adapt- ing and reinter- preting existing incompatible attributions}

2.3.1.3 Adding new compatible information and attributions

\subsubsection{Embracing inconsistency as a brand feature}

Seeing the workplaces was an eye-opener. That's what they do every single day, and obviously they get a certain pay per hour. We then also asked \{? [employee of the company]\}? if this work wasn't boring, and he just replied, "No they want it that way, they [...] want to do the same thing every day."/ Ever since then, it has always been a running gag: They want it that way. $\{$ ?[laughs] $\}$ ? And, yes, the company in general, well, that's how it is, how we kept it in mind.// (P36_Martha)

I am actually negatively biased when it comes to TO2,/ but it still appeals to me./ I find it neat./ You get a good overview about what they do, and it is done nicely with the magazine, and yeah, it does appeal to me, and compared to TO1, it is something where I would say that it has a concept behind it, and everything is done in the same style, and yes, I would rather apply for a job there./ (P24_Robert)

When you are looking for a job, I believe that with these brochures, they show clearly what they want and what possibilities their employees have./ They also show that new ideas are appreciated. [...]// I also have some old schoolmates who did internships there, and I also know some people who work there full-time./ They work for the technical department./ Yes, well, you only hear positive things./ It seems clear that they value their employees highly and that they make sure that they feel comfortable and also have their full support./ (P27_Adrian)

Due to me having no prior knowledge about this company and due to the fact that the two handouts have no connection in my opinion-/ Also, the whole material: this looks shiny, and the rest is matte, and that really doesn't fit together.//[...] Everything looks a little chaotic to me,/ and in some way this gives me the impression that they might also be chaotic as an employer. (P10_Joana) 
into perspective and paved the way for his construction of the employer's image as generally positive.

In these three ways, participants constructed consistent images of employers by reducing ambiguity and emphasizing homogeneity of various employer brand aspects. Our data shows that participants' fourth strategy to construct a plausible employer image was to embrace perceived contradictory brand features and assume that inconsistency was itself an expression of the employer image. In these cases, participants projected their frustration with perceived inconsistencies onto the employer and concluded that this inconsistency was a core feature of their employer brand. In this context, they subsequently actively constructed employer images that were built around themes of chaos, uncertainty, unreliability or lack of structure (Table 2, Code 2.3.2).

\subsection{Suspending and Withdrawing from Sensemaking}

If study participants grew frustrated during the process of making sense of employer brand material, they sometimes stopped constructing their personal idea of the employer. On one hand, this became visible when study participants temporarily suspended their engagement with the material. This happened, for instance, when potential applicants felt a need to take some more time to rethink or reconsider employer information (Table 3, Code 3.1.3) or when they felt that they needed to consult other sources or find more specific information (Code 3.1.1 and 3.1.2).

On the other hand, some potential applicants did not just suspend the process but completely withdrew from sensemaking. This happened firstly when company features (e.g., location, line of business) caused a general lack of interest in this particular employer (Table 3, Code 3.2.1). Secondly, potential applicants also withdrew from sensemaking if they were not willing to process what they perceived to be ambiguous attributions. For example, Dean concludes from his lack of a coherent image of company CE4 that he cannot formulate an opinion about it and subsequently shifts his focus to a different employer (Table 3, Code 3.2.2).

Both suspending and withdrawing from sensemaking took place during concurrent verbalization (phase 1) and during the retrospective inquiry (phase 2).

\subsection{Favorable and Unfavorable Assessments of Constructed Employer Images}

If participants were able to create a sufficiently strong idea of an employer's key features, they went on to assess the attractiveness of that employer. Images were deemed attractive or unattractive based on personal assessments that involved comparing relevant employers and contrasting perceived job or employer features to individuals' norms, ideals, experiences or expectations.

Participants frequently used comparisons with other employers to argue either for or against the assessed employer's attractiveness (Table 4, Code 4.1). The employers used as a point of reference were either other companies in the study or employers that potential applicants considered to be particularly relevant for the comparison of critical employer brand features. The features study participants addressed in their comparative assessments also indicated participants' values, ideals and work expec- 
Table 3 Codes associated with root 3, "Suspending the process or withdrawing from sensemaking"

\begin{tabular}{|c|c|}
\hline Code & Sample Quote \\
\hline \multicolumn{2}{|c|}{ 3.1 Suspending sensemaking } \\
\hline $\begin{array}{l}\text { 3.1.1 Suspending sense- } \\
\text { making because specific } \\
\text { contents are not available } \\
\text { in the situation }\end{array}$ & $\begin{array}{l}\text { The prospectus doesn't really say anything about the workplace because } \\
\text { they only introduce their products, but what they really do and what they } \\
\text { offer isn't clear./[...] I don't really know how they develop their main } \\
\text { product. }\{[\text { moves his right hand quickly across the page and puts the } \\
\text { prospectus away]\} (P13_Vincent) }\end{array}$ \\
\hline $\begin{array}{l}\text { 3.1.2 Suspending sense- } \\
\text { making because specific } \\
\text { types of information are } \\
\text { not available in the situa- } \\
\text { tion }\end{array}$ & $\begin{array}{l}\text { It is very difficult to express and describe the company culture in } \\
\text { a brochure./ That usually doesn't work/ }\{\text { [shakes his head] }\} \text { because you } \\
\text { can't describe people and their capability to work in teams or not./ Any- } \\
\text { one can say that the ability to work in a team is important and so on, but it } \\
\text { is such a subjective topic./ (P32_Brad) }\end{array}$ \\
\hline $\begin{array}{l}3.1 .3 \text { Moving on to the } \\
\text { next employer due to } \\
\text { individual time constraints }\end{array}$ & $\begin{array}{l}\text { Well, this is }\{[\text { reads it out loud] }\} \text { "Apprentice Project } 2012 . " \text { / Yes, I have } \\
\text { to put this aside because it really doesn't appeal to me right away./ One } \\
\text { probably really needs to sit down and take a moment to read through it in } \\
\text { detail./ (P45_Philip) }\end{array}$ \\
\hline
\end{tabular}

\subsection{Withdrawing from sensemaking}

\begin{tabular}{ll}
$\begin{array}{l}\text { 3.2.1 Withdrawing from } \\
\text { sensemaking due to a gen- } \\
\text { eral lack of interest in the } \\
\text { employer }\end{array}$ & $\begin{array}{l}\text { Since I don't spend much time in company location, I am not interested in } \\
\text { EE3./ I'd rather dismiss this. (P14_Henk) }\end{array}$ \\
$\begin{array}{l}\text { 3ensemaking due to frus- } \\
\text { tration }\end{array}$ & $\begin{array}{l}\text { This is ambiguous because I have heard some things./ Someone I know } \\
\text { works at CE4, and the thing with the gas stations happened there./ So, } \\
\text { I have no clear image. /[...] Um, yes,/I just-, I can't say much about this./ } \\
\{[\text { shakes his head] }\} \text { (P1_Dean) }\end{array}$ \\
\hline
\end{tabular}

tations. Aspects of personal and social identity and respondents' a priori schemas about what is important in their future work lives generally were the background against which potential applicants assessed the attractiveness of perceived employer images. For example, Victoria's reasoning for her decision to deem TO2 and TO4 to be unattractive employers (Table 4, Code 4.2.1.2) stressed her rejection of a highsociety lifestyle that she associated with the haughty and conceited image that she ascribed to these two employers. Dean, meanwhile, interpreted employer CE2's presentation of projects based on his professional commitment to questions of energy policy (Table 4, Code 4.2.1.1). Other aspects of individual identity affecting assessment processes were quality criteria and ideals used as frames of reference in the evaluation of an employer's that stemmed from previous work experiences and expertise (Table 4, Code 4.2.2.1) and from future work and career expectations (Table 4, Code 4.2.2.2).

\section{Discussion}

Based on our empirical findings, we present a process model that illustrates a central but flexible trajectory of how potential applicants make sense of employer brand material (Fig. 1). We argue that exploring the employer brand material, constructing a plausible employer image and assessing employer attractiveness represent the dominant sensemaking journey that potential applicants undertake when making 
Table 4 Codes associated with root 4, "Dynamics between schemas and frames-Favorable and unfavorable assessments of constructed images"

\begin{tabular}{|c|c|}
\hline Code & Sample Quote \\
\hline $\begin{array}{l}\text { 4.1. Framing perceived } \\
\text { job and company fea- } \\
\text { tures in relation to } \\
\text { those of other relevant } \\
\text { employers }\end{array}$ & $\begin{array}{l}\text { Stressful situations [...] I don't really need that because I don't want it if } \\
\text { I can avoid it./ There are other companies where it's not like that, where } \\
\text { the company takes care of the employees, and that is was I would want. } \\
\text { (P41_Bernie) }\end{array}$ \\
\hline \multicolumn{2}{|c|}{ 4.2 Framing perceived job and company features in relation to schemas } \\
\hline \multicolumn{2}{|c|}{ 4.2.1 Relating perceived job and company features to own identity features } \\
\hline $\begin{array}{l}\text { 4.2.1.1 Relating per- } \\
\text { ceived job and company } \\
\text { features to occupational } \\
\text { norms and ideals }\end{array}$ & $\begin{array}{l}\text { There are new construction projects that are introduced. / With the help of } \\
\text { these projects, one can classify what employers-, in which direction they } \\
\text { go-, which focus they have./ It would be interesting if they could-, What is } \\
\text { this? Probably, this is all about projects. }<3>\text { Now I wonder how relevant } \\
\text { energy-related topics are at CE2./ (P1_Dean) }\end{array}$ \\
\hline $\begin{array}{l}\text { 4.2.1.2 Relating per- } \\
\text { ceived job and company } \\
\text { features to social norms } \\
\text { and ideals }\end{array}$ & $\begin{array}{l}\text { I would never apply for a job at TO2 because I don't like the high-society } \\
\text { image./[...] I don't see myself going this direction in the future./ I'd rather } \\
\text { do something like this }\{[\text { points to TO3] }\} \text { that is real quality and not all } \\
\text { about seeing and being seen. (P31_Victoria) }\end{array}$ \\
\hline \multicolumn{2}{|c|}{ 4.2.2 Relating perceived job and company features to professional experiences and expectations } \\
\hline $\begin{array}{l}\text { 4.2.2.1 Relating per- } \\
\text { ceived job and company } \\
\text { features to work experi- } \\
\text { ences or career paths }\end{array}$ & $\begin{array}{l}\text { The then-manager was unbelievable./ He did an amazing job. He had every- } \\
\text { thing under control.// He wasn't a boss who just observes and commands./ } \\
\text { Those also really exist./ He actually helped and everything. [...]// That's } \\
\text { what I can say about TO2. (P11_Jules) }\end{array}$ \\
\hline $\begin{array}{l}\text { 4.2.2.2 Relating per- } \\
\text { ceived job and company } \\
\text { features to work expec- } \\
\text { tations or career plans }\end{array}$ & $\begin{array}{l}\text { There is no consistent line, and that's not for me./ I need something con- } \\
\text { sistent, something where I know everything fits together and is coherent,/ } \\
\text { because otherwise I'd be concerned that if I'd work there, it'd be just as } \\
\text { chaotic, and nothing would fit together. (P10_Joana) }\end{array}$ \\
\hline
\end{tabular}

sense of employer brand material. However, this trajectory is neither the only possible way nor completely linear and predictable since deviations, particularly the complete breakdown of making sense of employer brand material, are possible. In the following, we discuss the activities of the main trajectory, their interplay and deviations from the main trajectory.

\subsection{Exploring the Employer Brand Material}

"Sensemaking starts with chaos" (Weick et al. 2005, p. 411). At the beginning, potential applicants' engagement with the employer brand material was characterized by a blurred context and a fluid process. Chia (2000, p. 517) describes this early stage of sensemaking as "an undifferentiated flux of fleeting sense-impressions." We found that when potential applicants were confronted with employer material, they provided fragmentary comments on various aspects of the context and content but largely refrained from engaging with the material's integrated messages. Such ad hoc commentaries may lead to rough, diverse and disparate ideas about employers. Our study illustrates, however, that this is not a linear process, as participants experienced tensions, ambiguity and uncertainty in this context. For example, some cues were regarded negatively (e.g., useless, low-quality giveaways), while others related to the same employer were viewed positively (e.g., a program to support 


\begin{tabular}{|c|c|c|c|}
\hline & $\begin{array}{c}\text { Exploring } \\
\text { Employer Brand } \\
\text { Material }\end{array}$ & $\begin{array}{l}\text { Constructing } \\
\text { Employer } \\
\text { Image }\end{array}$ & $\begin{array}{l}\text { Assessing } \\
\text { Employer } \\
\text { Attractiveness }\end{array}$ \\
\hline & \multicolumn{3}{|c|}{ possibility of suspending the process or withdrawing from the process } \\
\hline foundations & $\begin{array}{l}\text { employer brand material } \\
\text { and individual a priori } \\
\text { concepts (schemas) }\end{array}$ & $\begin{array}{l}\text { selected employer brand } \\
\text { attributions, identity work } \\
\text { and active reasoning } \\
\text { (frames) }\end{array}$ & $\begin{array}{l}\text { constructed employer image } \\
\text { and identity projects }\end{array}$ \\
\hline criteria & general opportunity & subjective plausibility & personal relevance \\
\hline characteristics & $\begin{array}{l}\text { fragmentary, } \\
\text { fluid, heterogeneous }\end{array}$ & $\begin{array}{l}\text { aggregated, } \\
\text { emerging }\end{array}$ & $\begin{array}{c}\text { specific, } \\
\text { focused on selected aspects }\end{array}$ \\
\hline outcomes & attributions & image & (un)attractiveness \\
\hline expressions & $\begin{array}{l}\text { ad hoc commentaries; } \\
\text { tensions are possible and } \\
\text { likely }\end{array}$ & $\begin{array}{l}\text { meaningful story; } \\
\text { tensions resolved or } \\
\text { ignored }\end{array}$ & $\begin{array}{l}\text { interwoven story; } \\
\text { employment and life plans } \\
\text { connected to this employer }\end{array}$ \\
\hline actor's & distant & subjective & entangled \\
\hline position & actor as analyst & actor as storyteller & actor as protagonist \\
\hline
\end{tabular}

Fig. 1 Process model of sensemaking of employer brands

work-life balance of employees). Weick et al. (2005) regard noticing and bracketing as main activities in the early stage of making sense. Similarly, participants in our study tried to extract specific cues and aspects from the employer brand material for closer consideration. We conceptualize this process predominantly as priming, in which individuals describe what they see and read in the employer brand material and connect it to already-available mental models (Cornelissen and Werner 2014; Weick et al. 2005). These models mainly refer to knowledge about employment and general attitudes to work or to specific aesthetics or ideas in the provided material. In cases where the organization was already known to the participant, mental models were enriched with personal experiences as well as the experiences and opinions of others (e.g., peers). However, the empirical results also demonstrate evidence that participants had problems applying such mental models. These problems became apparent when potential applicants quickly moved to the next employer's box of brand material and therefore suspended their previous sensemaking process. Importantly, such suspensions did not necessarily lead to a breakdown of sensemaking for particular employers since some participants later examined the material again and continued exploring it.

The outcome of employer brand exploration is usually a fragmentary and heterogeneous set of attributes ascribed to an employer that are only loosely and vaguely connected to the participants' identity and work values. In only a few cases, potential applicants developed a robust, stable perspective on an employer rather early in the process, which we interpret as an overlap with the next activity. 


\subsection{Constructing a Plausible Employer Image}

During the second activity, potential applicants attempted to narrate a meaningful story about the organization as an employer. They did that by interpreting specific or general employer attributions and constructing a plausible employer image. This occurred through a process of active, deliberate reasoning that aimed to resolve tensions and ambiguities that arose in the previous activity of their sensemaking journey. These employer images were constructed subjectively, they were unique in their argumentation, diverse in their plausibility-driven interpretations and entrenched in the story that was crafted. However, this storytelling is usually not straightforward, as it may also include diverse attempts at making sense of contents, aesthetics and the type of employer brand material. In other words, it is a "continued redrafting of an emerging story so that it becomes more comprehensive [...] and is more resilient in the face of criticism" (Weick et al. 2005, p. 415). In the empirical results, this becomes visible, for instance, through potential applicants' attempts to retell previous employment experiences in light of the current impression of the employer brand material. This continued redrafting was fundamentally social since participants in our study also referred to the experiences of others and to discussions with peers, relatives or representatives of an employer. Moreover, by constructing a plausible employer image, the retrospective character of sensemaking (Weick 1995) becomes particularly evident. This is because interpretations of the present situation, here the consideration of employer brand material, are strongly influenced by past experiences, interactions and events. The future, in the form of employment options and desires, was already hinted at in the expressed thoughts of many participants but was not the focus of this sensemaking.

While constructing an employer image, some participants were reinforcing an already-activated schema to the extent that it was confirmed. Such sensemaking was based on an obvious, consistent and strong narrative and thus included few individual reflections from the exploration activity. Such denial of reflection created a situation in which participants' framing mainly legitimized and defended an already-developed perspective. However, the vast majority of participants explicitly reflected on the schemas that dominated their employer brand exploration. Consequently, their framing combined existing impressions with new ideas, thereby confirming and strengthening but also questioning and revising opinions formulated in 'exploring the employer brand material'. Interestingly, previous employment experiences (e.g., internships) usually did not fully determine potential applicants' construction of employer images. In this trajectory, participants went beyond their first assumptions and developed original frames. They related to these comments, returned to the material and substantiated or questioned former perspectives by connecting them to past work experiences, their present situation and ideas about their future employment and careers. This framing of employer brand material can be regarded as more substantial than priming since participants developed original views about the employers based on an ongoing process of reflecting on assumptions and an attempt to resolve contradictions and achieve consistency and clarity.

Participants related to the employer brand material and selected employer brand attributions but they also considered what this material and these attributions meant 
for them as individuals and for their values and self-concepts. Thus, constructing a plausible employer image can be regarded as a form of identity work. Potential applicants employed socio-cultural resources (such as general reputations of specific industries and structural characteristics of labor market segments) and personal memories and wishes (Alvesson and Willmott 2002) to identify and describe relevant aspects of their employer images. Simultaneously, they used "a variety of rhetorical devices, including accounts, stories, justifications, disclaimers, and other "vocabularies of motives"' (Ibarra and Barbulescu 2010, p. 137) to find answers to questions about what this employer image means for their identity. In doing this, they tried to meet their human needs for self-worth and confidence. Particularly, when employer brand material and company-created employer images irritated aspects of participants' identity, they usually attempted to understand this challenge and to stabilize or enhance their self-consistency and self-efficacy (Maitlis and Christianson 2014). This exposure to sensebreaking (Pratt 2000) provoked strong reactions in participants. They reconstructed their image of an employer or adapted aspects of their identity to make an employer more acceptable, or they strengthened and enforced their identity by devaluing an employer. However, others stopped the process of sensemaking because the identity they constructed in relation to an employer remained implausible. Usually, this took the form of an articulated need to return to employer brand exploration and study the material in greater detail. However, these suspensions had a different quality compared to sensemaking interruptions in 'exploring the employer brand material' since they were more significant and sustainable and were based on a more substantial effort to create a plausible connection to an employer.

We regard the successful construction of a plausible employer image as an essential step in making sense of employer brands. Potential applicants must be sufficiently confident in their construction of the employer's image in order to have a viable point of reference for their assessment of employers' attractiveness in the final activity of our process model.

\subsection{Assessing Employer Attractiveness}

The activity of employer attractiveness assessment potentially overlaps with the phase of employer image construction, but it is characterized by different characteristics. Here, the influence of the employer brand material and attributions diminishes, and potential applicants' identities, employment ideals and life plans, particularly future employment options, dominate. In this activity, the relationship between potential applicants and the employer shifts from exploration (first phase) and construction (second phase) to assessment. More precisely, potential applicants become evaluators of their prospective life courses in the context of their assessments of employer attractiveness. In this third phase, the prospective dimension of sensemaking comes to the forefront. Identity work becomes dominant, more specific and future driven as potential applicants assess employers in relation to their personal expectations regarding employment. The concept of identity projects thoroughly captures this feature of assessing the attractiveness of future employers (Appleby et al. 2018). Identity projects are "individuals' definitions of their selves in the light of their on- 
going development and imagined future" (Alvesson and Kärreman 2007, p. 713). Potential applicants relate their self-concepts to the individually created employer image and regard employers as either supporting, ignoring or threatening their identity projects (Appleby et al. 2018). To be able to make such viable judgments, participants in our study sought to develop a plausible narrative that convincingly captured perceived characteristics of the employer and connected them to their personal ideas on their future employment and careers. Thus, making sense of employer brand material with respect to the employers' attractiveness interweaves activated schemas and novel frames about an employer with the identity of the addressee of employer brand material. This process is beyond the control of the employer because it is highly subjective and represents an independent act of meaning creation (Aggerholm et al. 2011) that is triggered but in no way determined by the employer brand material. In this activity of assessing employer attractiveness, potential applicants relate their constructed employer image primarily to themselves and their identity projects, which then leads to clear rejections or approvals of employers.

\subsection{Breakdown of the Process of Making Sense of Employer Brands}

As our empirical data shows, the process of sensemaking can be severely disrupted and then break down completely. In other words, in some cases, participants stopped making sense of employer brands. Such withdrawals from sensemaking mainly occurred within two activities. Firstly, in employer brand exploration, terminations of sensemaking arose from the unwillingness or inability of participants to engage with and relate to the provided employer brand material, not even in very basic terms. Participants identified the low quantity or poor quality of information, time restrictions and insufficient interest in an employer as their main reasons for disengaging. The employer brand material is not able to trigger either sensemaking in the sense of creating meaning (Weick 1995) or sensebreaking in the sense of destruction of an existing individual meaning (Pratt 2000).

Secondly, withdrawals from sensemaking in the employer image construction occurred when participants were not able to resolve tensions, ambiguities and disinterest caused by the employer brand material, additional information, word of mouth or their own experiences. These participants were neither able nor willing to relate the employer to their future employment and life options. They preferred to abandon the sensemaking process rather than to positively or negatively assess an employer's attractiveness based on weak and unconvincing employer image constructions. This describes a situation in which potential applicants are not able to determine their connection with the employer and fail to plausibly construct their identity in relation to this employer. They develop neither a clear and constructive meaning of an employer nor seekership (Pratt 2000, p. 464) in the sense of increased motivation to learn more about an employer. Thus, potential applicants remain or become indifferent. In these situations, the process of sensemaking does not recover from a state of indifference. 


\section{Conclusion}

In investigating highly qualified potential applicants' processes of making sense of employer brand material, we conceptualized these process as unfolding in various activities that are not independent from each other. The function of the first activity of exploration is to orient oneself and therefore represents a necessary step before the construction of a plausible employer image in the second activity. Even more significant, this construction of an employer image constitutes a foundation of the individual assessment of employer attractiveness. This image represents an interpretation of attributions that potential applicants ascribe to features and contents of employer material and information. The construction of this image is a process of continued drafting of a subjectively plausible story and of potential applicants' identity work mainly based on personal work experiences and values. This image forms the main and essential point of reference for potential applicants' employer attractiveness judgment in that it is measured against personal schemas and frames that are fundamentally tied to the individual's identity projects. The intense influence of the potential applicant's specific identity project in relation to the respective employer, mainly based on future employment and career expectations, dominates the third phase of assessing the employers' attractiveness.

Our model implies that there are strong elements of interpretative uncertainty and unpredictability within the various activities of making sense of employer brand material. Additionally, specific deviations from the main trajectory described above are part of our model. Firstly, there is a possibility that potential applicants are not satisfied with their sensemaking process, the level of information they perceive or the plausibility of the constructed employer image. This situation can lead either to a temporary suspension or a complete withdrawal of potential applicants from making sense of employer brand material. The latter represents a strong uncertainty in the process of individual construction of employer brand images and derives from a breakdown of sensemaking because of indifference towards an employer and their brand material. Secondly, non-linear dynamics are possible within the process model. For example, potential applicants' schemas can be more prevailling than the main trajectory suggests. They can prevent potential applicants from integrating new aspects or information into their sensemaking (framing). This early determination of an employer image based on a small number of impressions and experiences leads to the phenomenon of selective redrafting and rationalization of an existing employer image. Preferences for and against employers are set based on limited information and criteria at an early stage, with the subsequent process focusing on confirming and rationalizing those early choices as a type of retrospective reasoning.

\section{Study Limitations and Further Research}

Contrary to the dominant positivistic and postpositivistic research, this study developed a process model of individuals' sensemaking of employer brand material. This model identifies various important aspects within this process, including the relevance of a plausible employer image and the possibility of a complete breakdown 
of individual meaning creation. However, there are some limitations to this study that are relevant to further research on employer branding.

Firstly, we did not fully explore the social dimension of framing in our study. Framing is characterized by "essentially dynamic and socially situated processes of meaning construction" (Cornelissen and Werner 2014, p. 183). We cover this social dimension in our study via past interactions and implied presence of others, which is an important part of the sociomaterial context of sensemaking (Maitlis and Christianson 2014). However, we did not cover social processes of constructing meanings of employer brands in the presence of other relevant agents (such as peers, family members, recruiters, etc.). To grasp this social dimension in the present, it would be necessary to observe communication processes between potential applicants (e.g., in focus groups) or between job seekers and recruiters, for example, at career fairs or during pre-hire mentoring (Smith 2018).

Secondly, we used real employer brand material provided by selected companies. These employers also had the freedom to choose the quantity and composition of their material. We chose this approach rather than standardized material from fictional companies because a research setting reflecting an authentic initial attraction best enabled us to explore potential applicants' interpretation of employer brand material in the context of existing impressions of employers. Several authors highlight the importance of using realistic scenarios in recruitment research to account for various facets of applicant reactions to employer information (e.g., Swider et al. 2015; Saks 2014). In this regard, the heterogeneity of employers and employer brand material used in our study are an advantage for our main study aim. However, we are unable to make any claims about isolated effects of the quantity or quality of the material or the existing employer image on perceived attractiveness of employers.

Thirdly, we did not systematically include important employer brand material such as company websites, employer's social media page (Carpentier et al. 2019) or company-independent information on social media (e.g., Sivertzen et al. 2013) and on platforms for employer evaluation. However, company-independent sources played a role in our empirical study when participants related to information on social media or platforms in the interviews. Qualitative empirical studies that explore potential applicants' processes of making sense of company websites, digital employer branding, social media and employer platforms could provide an important addition to current research on employer branding.

Acknowledgements We thank all members of the EBKOM research group for their helpful comments and gratefully acknowledge Maria Kreuzer's support in the development of this paper. The University of Innsbruck funded the open access publication of this article.

Author Contribution All authors contributed to this article, read and approved the final manuscript.

Open Access This article is licensed under a Creative Commons Attribution 4.0 International License, which permits use, sharing, adaptation, distribution and reproduction in any medium or format, as long as you give appropriate credit to the original author(s) and the source, provide a link to the Creative Commons licence, and indicate if changes were made. The images or other third party material in this article are included in the article's Creative Commons licence, unless indicated otherwise in a credit line to the material. If material is not included in the article's Creative Commons licence and your intended use is not permitted by statutory regulation or exceeds the permitted use, you will need to obtain permission directly from the copyright holder. To view a copy of this licence, visit http://creativecommons.org/licenses/by/4. $0 /$. 


\section{Compliance with ethical guidelines}

Conflict of interest M. Auer, G. Edlinger and A. Mölk declare that they have no competing interests.

Ethical standards Ethics approval and consent to participate are not applicable to this study because only data that are anonymized were used.

\section{References}

Acarlar, Gizem, and Reyhan Bilgiç. 2013. Factors influencing applicant willingness to apply for the advertised job opening: the mediational role of credibility, satisfaction, and attraction. The International Journal of Human Resource Management 24:50-77.

Aggerholm, Helle K., Sophie E. Andersen, and Christa Thomsen. 2011. Conceptualising employer branding in sustainable organisations. Corporate Communications: An International Journal 16:105-123.

Allen, David G., Raj V. Mahto, and Robert F. Otondo. 2007. Web-based recruitment: effects of information, organizational brand, and attitudes toward a web site on applicant attraction. Journal of Applied Psychology 92:1696-1708.

Allen, David G., James R. van Scotter, and Robert F. Otondo. 2004. Recruitment communication media: Impact on prehire outcomes. Personnel Psychology 57:143-171.

Alvesson, Mats, and Dan Kärreman. 2007. Unraveling HRM: identity, ceremony, and control in a management consulting firm. Organization Science 18:711-723.

Alvesson, Mats, and Hugh Willmott. 2002. Identity regulation as organizational control: producing the appropriate individual. Journal of Management Studies 39:619-644.

Ambler, Tim, and Simon Barrow. 1996. The employer brand. Journal of Brand Management 4:185-206.

Appleby, Kaitlin, Bernadette Bullinger, and Anna Schneider. 2018. STEM selves: women's identity projects and their assessment of future employers in technical fields. Scandinavian Journal of Management 34:311-325.

Backhaus, Kristin, and Surinder Tikoo. 2004. Conceptualizing and researching employer branding. Career Development International 9:501-517.

Barber, Alison E. 1998. Recruiting employees: individual and organizational perspectives. Thousand Oaks: SAGE.

Baum, Matthias, and Rüdiger Kabst. 2014. The effectiveness of recruitment advertisements and recruitment websites: indirect and interactive effects on applicant attraction. Human Resource Management 53:353-378.

Baum, Matthias, Marina Schäfer, and Rüdiger Kabst. 2016. Modeling the impact of advertisement-image congruity on applicant attraction. Human Resource Management 55:7-24.

Brown, Andrew D., Ian Colville, and Annie Pye. 2015. Making sense of sensemaking in organization studies. Organization Studies 36:265-277.

Cable, Daniel M., and Kang Y.T. Yu. 2006. Managing job seekers' organizational image beliefs: the role of media richness and media credibility. Journal of Applied Psychology 91:828-840.

Carlini, Joan, Debra Grace, Cassandra France, and Joseph Lo Iacono. 2019. The corporate social responsibility (CSR) employer brand process: integrative review and comprehensive model. Journal of Marketing Management 35:182-205.

Carpentier, Marieke, Greet van Hoye, and Bert Weijters. 2019. Attracting applicants through the organization's social media page: Signaling employer brand personality. Journal of Vocational Behavior 115:1-14.

Chen, Chien-Cheng, Mei-Mei Lin, and Chang-Ming Chen. 2012. Exploring the mechanisms of the relationship between website characteristics and organizational attraction. The International Journal of Human Resource Management 23:867-885.

Chia, Robert. 2000. Discourse analysis as organizational analysis. Organization 7:513-518.

Cober, Richard T., Douglas J. Brown, Lisa M. Keeping, and Paul E. Levy. 2004. Recruitment on the Net: How do organizational web site characteristics influence applicant attraction? Journal of Management 30:623-646.

Collins, Christopher J., and Adam M. Kamar. 2014. Employer brand equity and recruitment research. In The Oxford handbook of recruitment, ed. Trevor Kang Yang, Daniel M. Cable, 284-297. Oxford: Oxford University Press. 
Collins, Christopher J., and Cyntia K. Stevens. 2002. The relationship between early recruitment-related activities and the application decisions of new labor-market entrants: a brand equity approach to recruitment. Journal of Applied Psychology 87:1121-1133.

Coopey, John, Orla Keegan, and Nick Emler. 1997. Managers' innovations as 'sense-making'. British Journal of Management 8:301-315.

Cornelissen, Joep P. 2012. Sensemaking under pressure: the influence of professional roles and social accountability on the creation of sense. Organization Science 23:118-137.

Cornelissen, Joep P., and Jean S. Clarke. 2010. Imagining and rationalizing opportunities: inductive reasoning, and the creation and justification of new ventures. Academy of Management Review 35:539-557.

Cornelissen, Joep P., and Mirjan D. Werner. 2014. Putting framing in perspective: a review of framing and frame analysis across the management and organizational literature. The Academy of Management Annals 8:181-235.

Dickson, Janet, Jim McLennan, and Mary M. Omodei. 2000. Effects of concurrent verbalization on a timecritical, dynamic decision-making task. Journal of General Psychology 127:217-222.

Edwards, Martin R. 2010. An integrative review of employer branding and OB theory. Personnel Review 39:5-23.

Edwards, Martin R., and Tony Edwards. 2013. Employee responses to changing aspects of employer branding following a multinational acquisition: a longitudinal study. Human Resource Management 52:27-54.

Ericsson, K. Anders, and Herbert A. Simon. 1998. How to study thinking in everyday life: contrasting think-aloud protocols with descriptions and explanations of thinking. Mind, Culture, and Activity 5:178-186.

Eurochambres. 2019. Eurochambres economic survey. https://issuu.com/eurochambres/docs/ees_2019_ report_3.0. Accessed 18 Jan 2021.

Fox, Mark C., K. Anders Ericsson, and Ryan Best. 2011. Do procedures for verbal reporting of thinking have to be reactive? A meta-analysis and recommendations for best reporting methods. Psychological Bulletin 137:316-344.

Gioia, Dennis A., and Ajay Mehra. 1996. Book review: Sensemaking in organizations. Academy of Management Reviews 21:1226-1230.

Gumperz, John J., and Norine Berenz. 1993. Transcribing conversational exchanges. In Talking data: transcription and coding in discourse research, ed. Jane A. Edwards, Martin D. Lampert, 91-121. Hillsdale: Lawrence Erlbaum.

Heisley, Deborah D., and Sidney J. Levy. 1991. Autodriving: a photoelicitation technique. The Journal of Consumer Research 18:257-272.

Hinojosa, Amanda S., H. Jack Walker, and G. Tyge Payne. 2015. Prerecruitment organizational perceptions and recruitment website information processing. The International Journal of Human Resource Management 26:2617-2631.

Ibarra, Herminia, and Roxana Barbulescu. 2010. Identity as narrative: prevalence, effectiveness, and consequences of narrative identity work in macro work role transitions. Academy of Management Review 35:135-154.

Jansen, Karen J., and Abbie J. Shipp. 2019. Fitting as a temporal sensemaking process: shifting trajectories and stable themes. Human Relations 72:1154-1186.

Kashive, Neerja, and Vanada T. Khanna. 2017. Study of early recruitment activities and employer brand knowledge and its effect on organization attractiveness and firm performance. Global Business Review 18:172-190.

King, Nigel. 2012. Doing template analysis. In Qualitative organizational research: core methods and current challenge, ed. Catherine Cassell, Gillian Symon, 426-450. Thousand Oaks: SAGE.

Kröll, Claudia, Stephan Nüesch, and J. Nils Foege. 2018. Flexible work practices and organizational attractiveness in Germany: the mediating role of anticipated organizational support. The International Journal of Human Resource Management 30:1505-1525.

Kumari, Shweta, and Gordhan K. Saini. 2018. Do instrumental and symbolic factors interact in influencing employer attractiveness and job pursuit intention? Career Development International 23:444-462.

Lahlou, Saadi, Sophie Le Bellu, and Sabine Boesen-Mariani. 2015. Subjective evidence-based ethnography: theory and case studies. Integrative Psychological and Behavioral Science 49:216-238.

Langley, Ann, Clive Smallman, Haridimos Tsoukas, and Andrew van de Ven. 2013. Process studies of change in organizations and management: unveiling temporality, activity, and flow. Academy of Management Journal 56:1-13. 
Lievens, Filip. 2007. Employer branding in the Belgian army: the importance of instrumental and symbolic beliefs for potential applicants, actual applicants, and military employees. Human Resource Management 46:51-69.

Lievens, Filip, and Scott Highhouse. 2003. The relation of instrumental and symbolic attributes to a company's attractiveness as an employer. Personnel Psychology 56:75-102.

Lievens, Filip, and Jerel E. Slaughter. 2016. Employer image and employer branding: what we know and what we need to know. Annual Review of Organizational Psychology and Organizational Behavior 3:407-440.

Maitlis, Sally, and Marlys Christianson. 2014. Sensemaking in organizations: taking stock and moving forward. Academy of Management Annals 8:57-125.

Martin, Graeme, Paul J. Gollan, and Kerry Grigg. 2011. Is there a bigger and better future for employer branding? Facing up to innovation, corporate reputations and wicked problems in SHRM. The International Journal of Human Resource Management 22:3618-3637.

Onken-Menke, Greta, Stephan Nüesch, and Claudia Kröll. 2018. Are you attracted? Do you remain? Metaanalytic evidence on flexible work practices. Business Research 11:239-277.

Petty, Richard E., and John T. Cacioppo. 1981. Attitudes and persuasion: classic and contemporary approaches. Dubuque: William C. Brown.

Pratt, Michael G. 2000. The good, the bad, and the ambivalent: managing identification among Amway distributors. Administrative Science Quarterly 45:456-493.

Saks, Alan M. 2014. How do study recruitment? A consideration of the issues and complexity of designing and conducting recruitment research. In The Oxford handbook of recruitment, ed. Kang Yang T. Yu, Daniel M. Cable, 463-491. Oxford: Oxford University Press.

Sandberg, Jörgen, and Haridimos Tsoukas. 2014. Making sense of the sensemaking perspective: its constituents, limitations, and opportunities for further development. Journal of Organizational Behavior 36:6-32.

Sengupta, Atri, Umesh Bamel, and Pankaj Singh. 2015. Value proposition framework: implications for employer branding. Decision 42:307-323.

Sivertzen, Anne-Mette, Etty R. Nilsen, and Anja H. Olafsen. 2013. Employer branding: employer attractiveness and the use of social media. Journal of Product \& Brand Management 22:473-483.

Smith, Leo. 2018. Storytelling as fleeting moments of employer brand co-creation. https://pure.au.dk/ portal/files/143274123/Final_Text.pdf. Accessed 18 Jan 2021. Aarhus University.

Stockman, Sara, Greet van Hoye, and Serge da Motta Veiga. 2020. Negative word-of-mouth and applicant attraction: the role of employer brand equity. Journal of Vocational Behavior 118:103368.

Swider, Brian W., Ryan D. Zimmerman, Steven D. Charlier, and Abigail J. Pierotti. 2015. Deep-level and surface-level individual differences and applicant attraction to organizations: a meta-analysis. Journals of Vocational Behavior 88:73-83.

Theurer, Christian P., Andranik Tumasjan, Isabell M. Welpe, and Filip Lievens. 2018. Employer branding: a brand equity-based literature review and research agenda. International Journal of Management Reviews 20:155-179.

Uggerslev, Krista L., Neil E. Fassina, and David Kraichy. 2012. Recruiting through the stages: a metaanalytic test of predictors of applicant attraction at different stages of the recruiting process. Personnel Psychology 65:597-660.

Van Hoye, Greet, and Filip Lievens. 2009. Tapping the grapevine: a closer look atword-of-mouth as a recruitment source. Journal of Applied Psychology 94:341-352.

Van Hoye, Greet, Bas Turker, Saartje Cromheecke, and Filip Lievens. 2013. The instrumental and symbolic dimensions of organizations' image as an employer: a large-scale field study on employer branding in Turkey. Applied Psychology: An International Review 62:543-557.

Walker, H. Jack, and Amanda S. Hinojosa. 2014. Recruitment: the role of job advertisements. In The Oxford handbook of recruitment, ed. Daniel M. Cable, Kang Yang T. Yu, 269-283. Oxford: Oxford University Press.

Walker, H. Jack, Hubert S. Field, William F. Giles, Jeremy B. Bernerth, and Jeremy C. Short. 2011. So what do you think of the organization? A contextual priming explanation for recruitment Web site characteristics as antecedents of job seekers' organizational image perceptions. Organizational Behavior and Human Decision Processes 114:165-178.

Weber, Klaus, and Mary Ann Glynn. 2006. Making sense with institutions: context, thought and action in Karl Weick's theory. Organization Studies 27:1639-1660.

Weick, Karl E. 1993. The collapse of sensemaking in organizations: the Mann Gulch disaster. Administrative Science Quarterly 38:628-652.

Weick, Karl E. 1995. Sensemaking in organizations. Thousand Oaks: SAGE. 
Weick, Karl E., Kathleen M. Sutcliffe, and David Obstfeld. 2005. Organizing and the process of sensemaking. Organization Science 16:409-421. 